\title{
Berpenampilan Menarik (Sketsa Budaya Konsumerisme dan Eksistensi Perempuan di Dunia Kerja)
}

Conference Paper · April 2015

CITATIONS

0

1 author:

\section{Pangeran Nasution}

Universitas Malikussaleh

4 PUBLICATIONS 0 CITATIONS

SEE PROFILE
READS

49

Some of the authors of this publication are also working on these related projects:

Project

Syar'i Tourism View project

Project

Food Securities View project 

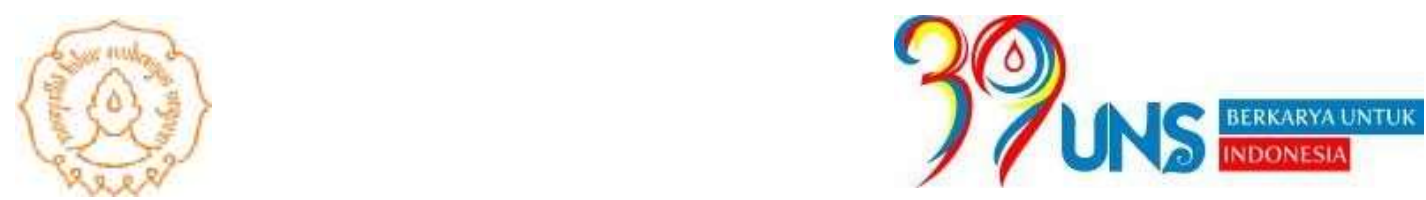

\section{PROSIDING}

Seminar Nasional Ilmu Sosial dan Ilmu Politik (SNISIP) FISIP UNS dengan tema Gender Politik dan Pembangunan di Indonesia: Perspektif Multidisiplin

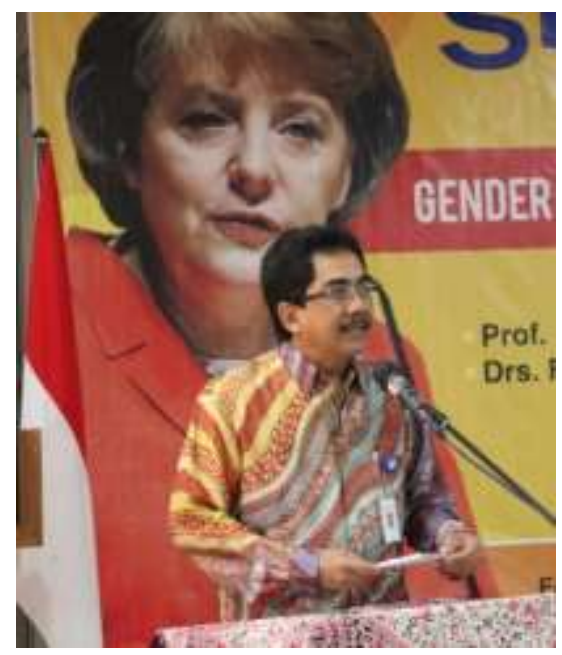

\section{PEMBICARA UTAMA:}

1. Prof. Dr. Ir. Keppi Sukesi, M.S. (Universitas Brawijaya, Malang)

2. Drs. Fathan (Anggota DPR RI)

3. Dr. Widodo Muktiyo, S.E., M.Kom. (Universitas Sebelas Maret, Surakarta)

4. Prof. Dr. Ismi Dwi Astuti N., M.Si. (Universitas Sebelas Maret, Surakarta)

\section{EDITOR:}

1. Dr. Sri Hidayati. M.Si. (Universitas Trunojoyo, Madura)

2. Dr. Rusdi, M.Hum. (IKIP Budi Utomo, Malang)

3. Dr. Ahmad Zuber, S.Sos., D.E.A. (Universitas Sebelas Maret, Surakarta)

4. Sri Hastjarjo, S.Sos., Ph.D. (Universitas Sebelas Maret, Surakarta)

5. Siti Zunariyah, S.Sos., M.Si. (Universitas Sebelas Maret, Surakarta) 
Dipublikasikan dan dicetak oleh UNS PRESS

J1. Ir. Sutami, 36A Surakarta, Indonesia 57126

\section{Anggota IKAPI}

Perpustakaan Nasional Katalog Dalam Terbitan (KDT) Hidayati, Sri, dkk.

Gender Politik dan Pembangunan di Indonesia: Perspektif Multidisiplin Hidayati, Sri, dkk., - Surakarta

UNS Press, 2015 xiii. 19 × 26

$\mathrm{cm}$

ISBN: 978-979-498-972-2

Hak cipta dilindungi oleh undang-undang

All rights reserved

Isi di luar tanggung jawab percetakan 
Marilah kita memanjatkan puji syukur kepada Tuhan yang Maha Kuasa. Atas berkah dan karunianya kita dapat saling bertemu dalam acara yang indah ini.

Kami dengan senang hati menyelenggarakan Call for Papers Seminar Nasional Ilmu Sosial dan Ilmu Politik (SNISIP) dengan tema "Gender Politik dan Pembangunan di Indonesia: Perspektif Multidisiplin" dalam rangka Dies Natalis UNS ke 39. Kami telah berusaha semaksimal mungkin untuk memberikan yang terbaik. Atas terselenggaranya kegiatan ini kami menyampaikan terima kasih kepada Bapak Prof. Dr. Ravik Karsidi, M.S., Rektor

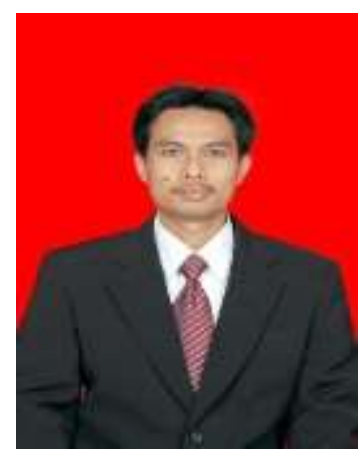
Universitas Sebelas Maret; Dr. Wisnu Untoro, M.S., Ketua Umum Dies natalis UNS ke 39, Bapak Prof. Drs. H. Pawito, Ph.D., Dekan FISIP UNS, semua pembicara, dan seluruh peserta yang hadir dalam kesempatan yang bahagia ini.

Dalam kegiatan SNISIP 2015 ini dihadiri dari para akademisi, para pengamat sosial politik, para pembuat kebijakan publik kurang lebih 200 orang.

Atas terselenggarannya kegiatan ini kami juga menyampaikan terima kasih kepada seluruh panitia dan seluruh mahasiswa yang terlibat di kapanitiaan. Jika ada kurang lebihnya kami mohon maaf.

Selamat menikmati suasana seminar, dan menikmati kunjungan Surakarta yang tidak terlupakan. Kami berharap akan ketemu lagi di acara SNISIP FISP UNS tahun yang akan datang.

Surakarta, 22 April 2015

Dr. Ahmad Zuber, S.Sos., D.E.A.

Ketua Panitia Pelaksana 


\section{Sambutan Dekan FISIP Universitas Sebelas Maret Surakarta}

Selamat pagi

Assalamualaikum Warrohamtullahi Wabarokatuh

Yang saya hormati Bapak Prof. Dr. Ravik Karsidi, M.S., Rektor Universitas Sebelas Maret Surakarta; seluruh Dekan di lingkungan Universitas Sebelas maret Surakarta; seluruh pembicara: Ibu Prof. Dr. Keppi Sukesi (Universitas Brawijaya, Malang), Bapak Drs. Fathan Subchi (Anggota DPR RI), dan Ibu Prof. Dr. Ismi Dwi Astuti Nurhaeni dari Universitas Sebelas Maret, Surakarta.

Yang saya hormati seluruh peserta seminar nasional

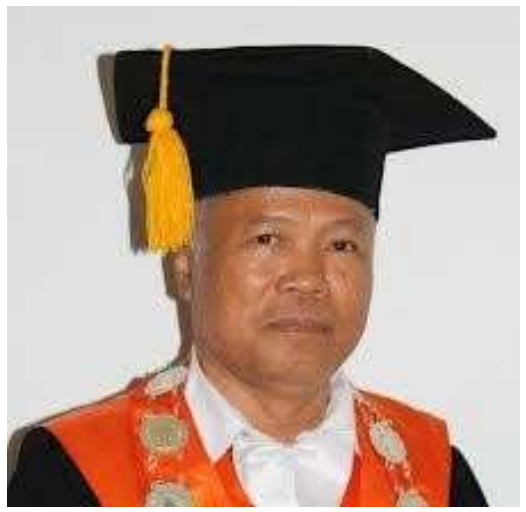
pada pagi hari ini.

Selamat datang di Kota Surakarta, kota yang penuh dengan dinamika untuk menuju kota modern di tanah Jawa, dan sebagai kota dimana Universitas Sebelas Maret ini berada.

Selaku Dekan FISIP Universitas Sebelas Maret Kami sangat mendukung secara penuh kegiatan seminar nasional pada pagi hari ini dengan tema "Gender Politik dan Pembangunan di Indonesia: Perspektif Multidisiplin"

Kami berharap kegiatan-kegiatan seperti ini dapat lebih ditingkatkan kualitas dan kuantitasnya untuk menjadikan Universitas Sebelas Maret menuju World Class University.

Kami berkomitmen untuk meningkatkan sarana dan prasana pendukung supaya kita dapat berperan secara baik di hadapan universitas-universitas yang berlabel world class university, antara lain kami dorong seluruh sivitas akademika di lingkungan FISIP UNS untuk melakukan kegiatan penulisan yang terindek SCOPUS, dan juga mendorong kegiatan ini dapat dipublikasikan dalam bentuk proceeding.

Kami mengucapakan terima kasih kepada seluruh panitia yang dikoordinir oleh Dr. Ahmad Zuber, terima kasih atas semua perhatian dan kerja kerasnya sehingga seminar nasional pada pagi hari ini dapat terselenggara dengan baik.

Saya berharap melalui seminar nasional ini tercipta ikatan yang kuat di antara para profesional akademikus, para analis ilmu sosial dan ilmu politik, para pembuat kebijakan publik, dan juga para wartawan bidang ilmu sosial dan ilmu politik.

Selamat berseminar dengan penuh perhatian dan kesungguhan. Semoga Tuhan YMK memberkahi kita. Amin Terima kasih.

Wassalamualaikum Warrohamtullahi Wabarokatuh

Surakarta, 22 April 2015

Prof. Drs.H. Pawito, Ph.D

Dekan FISIP, Universitas Sebelas Maret (UNS)

Surakarta, Indonesia 


\section{Selamat pagi}

Assalamualaikum Warrohamtullahi Wabarokatuh

Yang saya hormati seluruh Dekan di lingkungan

Universitas Sebelas maret Surakarta, secara khusus Bapak Prof. H. Pawito, Ph.D., Dekan Fakultas Ilmu Sosial dan Ilmu Politik, Universitas Sebelas Maret,

Yang saya hormati seluruh pembicara: Ibu Prof. Dr. Keppi Sukesi (Universitas Brawijaya, Malang), Bapak Drs. Fathan Subchi (Anggota DPR RI), Bapak Prof. H. Pawito, Ph.D. dan Ibu Prof. Dr. Ismi Dwi Astuti Nurhaeni dari Universitas Sebelas

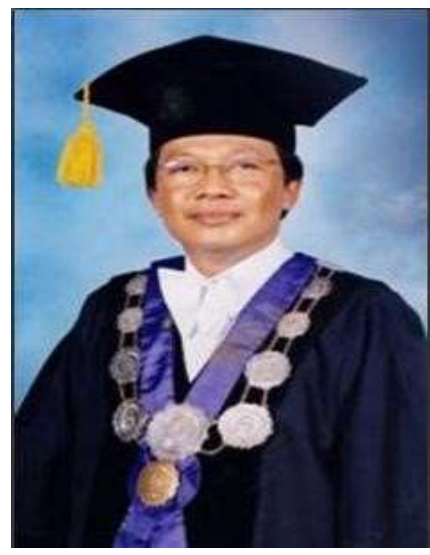
Maret, Surakarta.

Yang saya hormati seluruh peserta seminar nasional pada pagi hari ini.

Selamat datang di Kota Surakarta, kota yang penuh nuansa budaya Jawa, dan tempat dimana Universitas Sebelas Maret ini berdiri tegak.

Sebagai Pimpinan Universitas Sebelas Maret kami berkomitmen Universitas Sebelas Maret untuk menuju World Class University. Sebagai universitas yang bertaraf kelas dunia kami mendorong kegiatan-kegiatan ilmiah sivitas akademika baik yang berskala nasional maupun interansional. Untuk itu kegiatan seminar nasional ilmu sosial dan ilmu politik dengan tema "Gender Politik dan Pembangunan di Indonesia: Perspektif Multidisiplin" ini sangat penting.

Kami berharap dari kegiatan seminar nasional dengan tema "Gender Politik dan Pembangunan di Indonesia: Perspektif Multidisiplin” ini dapat membuka wacana kepada kita tentang persoalan gender, politik, dan pembanguan di Indonesia. Kemudian setelah itu kita dapat memberikan resolusi yang tebaik berkaitan dengan persoalan gender, politik dan pembangunan yang kita hadapi bersama di negeri Indonesia yang tercinta ini.

Bapak/ Ibu yang saya hormati,

Selamat mengikuti dan menikmati seminar nasional pada pagi hari ini.

Atas nama Universitas Sebelas Maret dan Panitia, secara resmi saya nyatakan dibuka seminar nasional ilmu sosial dan ilmu politik dengan tema "Gender Politik dan Pembangunan di Indonesia: Perspektif Multidisiplin.

Terima kasih.

Wassalamualaikum Warrohamtullahi Wabarokatuh

Surakarta, 22 April 2015

Prof. Dr. Ravik Karsidi, M.S.

Rektor Universitas Sebelas Maret (UNS)

Surakarta, Indonesia 


\section{Daftar ISI}

Sambutan Selamat Datang Ketua Panitia

Dr. Ahmad Zuber, S.Sos., D.E.A

Sambutan Dekan FISIP Universitas Sebelas Maret Surakarta

Prof. Drs. Pawito, Ph.D.

Sambutan Rektor Universitas Sebelas Maret Surakarta

Prof. Dr. Ravik Karsidi, M.S.

Daftar Isi

Susunan Panitia viii

\section{Sesi Pleno (Pembicara Utama)}

1 Keppi Sukesi

Gender dan Kemiskinan di Indonesia

2 Ismi Dwi Astuti Nurhaeni; Rara Sugiarti; Sri Marwanti

ENGENDERING DEVELOPMENT: CASE STUDY ON ECO-TOURISM

(Menggenderkan Pembangunan: Studi Kasus pada Pembangunan Pariwisata

Ramah Lingkungan)

\section{Sesi Paralel}

1 Agus Naryoso

Mediasi Komunikasi Untuk Mengurai Problematika PSK Pasar Kembang

Yogyakarta

2 Agustina Siahaan; Dimas Rizky Putranto; Nyphadear TSAP; Argyo Demartoto Penggunaan Aplikasi I-Dating Bagi Komunitas Gay Di Surakarta sebagai

Aktualisasi Hak Atas Public Life

3 Ahmad Zuber

Perubahan Agraria di Masyarakat Pedesaan Indonesia: Faktor-Faktor dan 
4 Aiddaris Budiah; Hardi Alunaza SD

Kepemimpinan Tri Rismaharini Sebagai Bentuk Partisipasi Perempuan Dalam

Politik Dan Pembangunan Di Era Digital

5 Andrik Purwasito

Mainstreaming Gender, Imageri Budaya and Bargaining Position ..........

6 Anif Fatma Chawa; Aris Setiawan

Perempuan Pekerja Home Industry dan Kesehatan

7 Anna C. Suwardi

Partisipasi Politik Perempuan Aceh Pasca Konflik Ditinjau dari Aspek

Perdamaian Positif

8 Annisa Setya Hutami

Sorotan Media Terhadap Women Leadership

9 Argyo Demartoto; RB. Soemanto; Siti Zunariyah

Menjadi Ibu Rumah Tangga Peduli Aids Melalui Pendidikan Kelompok

Sebaya Terstruktur

10 Ayu Kusumastuti

Jalan Ketiga Nasionalisasi dan Privatisasi: Ambivalensi Kebijakan Pengelolaan Sumber Daya Air di Indonesia

11 Ayusia Sabhita Kusuma

Strategi Pengarusutamaan Gender di Indonesia

dalam Tantangan Negara Pembangunan Berorientasi Pasar

12 Bagus Haryono

Nasionalisme Kalangan Grass Root di Kota Surakarta: Mereduksi Ideologi

Dalam Simbol

13 Budiarjo

Kesiapan Pemangku Kepentingan di Wilayah Perbatasan dalam Menyongsong

Masyarakat ASEAN

14 Budiawati Supangkat; Johan Iskandar

Politik Perempuan Pedagang Di Pasar Tradisional Bandung

15 Caroline Paskarina

Mengatur Kebahagiaan: Memaknai Indeks Kebahagiaan Sebagai Instrumen

Kebijakan Pembangunan

16 Chatia Hastasari; Paramstu Titis Anggitya; Erwin Kartinawati 
Budaya "Klik Share" Pada Akun Facebook Sebagai Partisipasi Politik Di Era Digital

17 Damar Sari Wulan

Peran "Gen Y Women" Dalam Pembangunan Indonesia Masa Depan ....

18 Dewi Gunawati

Menelisik Implementasi Program Reducing Emmision Deforestation

And Forest Degradation Dalam Pembangunan Hutan Lestari Di

Indonesia

19 Diah Puspaningrum

Model Pembangunan Alternatif Berbasis Masyarakat Pada Taman Nasional

Meru Betiri

20 Didik G. Suharto

Kesetaraan Dan Keadilan Gender Dalam Manajemen Aparatur Sipil Negara

(Suatu Kajian Terhadap Uu Nomor 5 Tahun 2014 Tentang Aparatur Sipil

Negara)

21 Dyah Retno Pratiwi; Rahmat Wisudawanto Diskriminasi Gender Sebagai Refleksi

Kekuasaan (Sebuah Studi Kasus Komunikasi

Antar Budaya dalam Film Anna And The King) 277

22 Elly Malihah; Idrus Affandi; Diani Risda; Leni Anggraeni

Perempuan Dan Politik: Pengalaman Indonesia-Jepang

23 Faizatul Ansoriyah

Governance Dalam Pengelolaan Zakat (Suatu Tinjauan Terhadap UU No. 23

Tahun 2011 Tentang Pengelolaan Zakat)

24 Firdastin Ruthnia Yudiningrum

Upacara Ritual Mahesa Lawung Keraton Surakarta: Media Komunikasi

Budaya

25 George Mentansan

Dominasi Modernitas Dalam Masyarakat Adat Raja Ampat (Studi Kasus Di

Kota Waisai Kabupaten Raja Ampat, Provinsi Papua Barat)

26 Grendi Hendrastomo; Nur Endah Januarti

Orientasi Dan Partisipasi Politik Pemilih Pemula

27 I Ngurah Suryawan

Kitong Pu Tanah: Terbentuknya Elit Lokal Dalam Pemekaran Daerah Di

Kabupaten Manokwari Selatan, Provinsi Papua Barat

28 Ikma Citra Ranteallo

Mengurai Simpul Kekuasaan Internasional Pada Indigenous Knowledge

Berbasis Gender Dan Perubahan Iklim

29 Imam Yuliadi; M. Chairul Basrun Umanailo

Mereduksi Multipartai Untuk Kestabilan Pembangunan Nasional

30 Indhar Wahyu Wira Harjo

Pengawasan Semu Perempuan Perkara Implementasi Kebijakan Pemerintah 
Indonesia

31 Jefta Leibo'; Sri Yuliani ${ }^{2}$; Rahesli Humsona

Mengembangkan Kebijakan Mitigasi Bencana Berbasis Kebutuhan Gender :

Studi Di Kota Surakarta

32 Juliana Kurniawati

Partisipasi Politik Perempuan Melalui “Media Baru” Di Bengkulu

33 Ledyawati

Perubahan Infrastruktur Perempuan Pemulung Batubara (Studi Kasus

Perubahan Okupasi dari Pertanian ke Pertambangan di Desa Penanding

Bengkulu Tengah)

406

34 Leni Winarni

Krisis Identitas Politik Kebangsaan, Pembangunanketahanan Nasional, Dan Isu

Radikalisme Islam Di Indonesia

35 Lestariningsih; Rahesli Humsona; Thomas Aquinas Gutama

Pengembangan Kebijakan Bantuan Tunai Model CCTs Untuk Mendukung

Efektivitaskebijakan Kompensasi BBM

428

36 Lesti Heriyanti

Analisis Faktor Yang Melatar-Belakangi Partisipasi Perempuan Nelayan

Dalam Proses Pemilihan Umum

37 Linda Safitra

Pengarusutamaan Gender Versus Budaya Patriarki "Pembahasan Sosiologis

Tentang Keterlibatan Perempuan Dalam Program Nasional Pemberdayaan

Masyarakat Mandiri Perdesaan (PNPM MP) Di Nagari Batu Bulek, Kecamatan

Lintau Buo Utara, Kabupaten Tanah Datar Sumatera Barat Tahun 2010 ...

38 Lukas Maserona Sarungu

New Media Dan Demokrasi Di Era Digital: Sebuah Tinjauan Kritis

Menggunakan Perspektif Fiske

39 Lukman Fahmi Djarwono

Gender Dan Reformasi Sektor Keamanan Di Indonesia Menjelang Asean

Community 2015

40 Mara Densa Ahmad Nuh Siregar

Televisi Dan Personalisasi Politik Di Indonesia:

Iklan Politik, Upaya Dan Efek Terhadap Perilaku Memilih

41 Masduki

Media Dan Male-Politic: Independensi Newsroom Ditengah Oligarki

Media Pada Pemilu 2014

42 Maya Sandra Rosita Dewi

Partisipasi Politik Perempuan Muda Dalam Memperjuangkan Wacana

Kesetaraan Gender

43 Monika Sri Yuliarti

Twitter Dan Partisipasi Politik Pemilih Pemula Dalam Pemilihan Umum ...

44 Rr Nanik Setyowati 
Partisipasi Politik Di Era Digital Dalam Rangka Pembentukan Warga Negara Yang Baik (Be A Good Citizen)

45 Nazrina Zuryani

Partai Politik Di Bali: Kajian Wawasan Lokal-Regional Dalam Representasi

Perempuan Hasil Pemilu Legislatif 2014

46 Ninik Sri Rahayu

Model Pemberdayaan Perempuan Miskin Pasca Bencana: Studi Di Lereng 531 Merapi

47 Nurbayti

Perempuan Etnis Papua Di Ruang Publik (Minimnya Peranan Perempuan

Etnis Papua Pada Unit Kegiatan Mahasiswa Di Universitas Gajah Mada) ....

48 Nur Dyah Gianawati

Keterwakilan Politik Perempuan Yang Berkeadilan Dalam Praktek Demokrasi

Di Indonesia

49 Oksiana Jatiningsih

Stagnasi Transformasi Gender Menuju Egalitarian Di Lembaga Pendidikan

Tenaga Kependidikan

50 Pangeran P.P.A. Nasution

Berpenampilan Menarik (Sketsa Budaya Konsumerisme Dan Eksistensi

Perempuan Di Dunia Kerja)

51 Randhi Satria

Gender Dan Kriminal Peran Perempuan Dalam Dunia Peredaran Narkoba Di

Indonesia

52 Dhyah Ayu Retno Widyastuti; dan Ranggabumi Nuswantoro

Dinamika Politik Perempuan Di Era Digital Studi Deskriptif Praktek Politik \&

Demokrasi Perempuan Dalam Komunitas Emak Blogger (Keb)

53 RB. Soemanto

Sektor Sosial Ekonomi Produktif Dan Perubahan Sosial Perempuan .......

605

54 Riris Ardhanariswari; Sofa Marwah

Political Will Pemerintah Daerah Untuk Meningkatkan Kesejahteraan

Perempuan Perajin Batik Banjarnegara Melalui Rintisan Pendirian Koperasi

Batik

55 Rr Sita Dewi Kusumaningrum 621

DESENTRALISASI FISKAL DAN PEMBANGUNAN GENDER Di INDONESIA

56 Rr Nanik Setyowati

Partisipasi Politik Di Era Digital Dalam Rangka Pembentukan Warga Negara

Yang Baik (Be A Good Citizen)

57 Salieg Luki Munestri

Program Asi Eksklusif Sebagai Upaya Mewujudkan Tujuan Pembangunan

Milenium Bidang Kesehatan Anak Dan Permasalahan Pojok Asi: Studi Di

Kota Surakarta

58 Septyanto Galan Prakoso; Mentari Dhea Arisanova; Wahyu Candra Dewi

Pengarusutamaan Gender sebagai Unsur Signifikan bagi Pemberdayaan 
Sumber daya Manusia di Indonesia

59 Sigit Pranawa

Mengurangi Dampak Pergeseran Okupasi Dari Sektor Pertanian Ke

Pertambangan Di Sekitar Pt Antam Pongkor

664

60 Sindung Haryanto

Rekonstruksi Maskulintas, Pemberdayaan Perempuan Dan Kesetaraan Gender

675

61 Siti Komariah

Implementasi Nawacita Dalam Pemberdayaan Perempuan Di Indonesia;

(Kajian Upaya Meningkatkan Peranan Dan Keterwakilan Perempuan Dalam

Politik)

62 Siti Nurbayani K

Pemberdayaan Dalam Bidang Pendidikan Bagi Perempuan Pada Suku Dayak

Hindu Budha Bumi Segandhu Indramayu

63 Siti Zunariyah

Peranan Perempuan Dalam Pengelolaan Dan Pelestarian Sumberdaya Alam

709

64 Sofiah

Literasi Digital Dan Perlindungan Hak Anak (Pengembangan Literasi Digital

Oleh Radio Komunitas Difabel Tunanetra "Sahabat Mata" Untuk Memberi

Perlindungan Terhadap Hak Anak)

720

65 Sri Endah Kinasih

Membangun Model Kemandirian Sebagai Upaya Pengentasan Kemiskinan

Pada Keluarga Purna Buruh Migran Perempuan Di Jawa Timur

66 Sri Herwindya Baskara Wijaya

Internet Meme Dan Visualisasi Politik Indonesia

67 Sri Hilmi Pujihartati

Kepemimpinan Jokowi Diuji Di Awal Pemerintahannya ..................

68 Sri Suwartiningsih

Hubungan Kolegeal Perempuan dan Laki-Laki dalam Arena Politik dan

Pembangunan

69 Sri Yuliani; Rina Herlina Haryanti; Rahesli Humsona

Hambatan Dalam Mengembangkan Partisipasi Anak Dalam Perencanaan

Pembangunan Berbasis Human Governance : Kasus Forum Anak Di Kota

Surakarta

70 Sudarmo

Implikasi Pemilihan Alternatif Kebijakan Berbasis Kepentingan Elit Terhadap

Respon Para Stakeholder Dan Potensi Marginalisasi Pedagang Kaki Lima Di

Wilayah Perkotaan Kabupaten Klaten

71 Surifah; Rahmawati

Pengaruh Board Governance Terhadap Efisiensi Perbankan Indonesia .......

72 Ucca Arawindha; Titi Fitrianita 
Pemberdayaan Lsm Paramitra Pada Odha Perempuan Di Malang

73 Tiyas Nur Haryani

Perempuan, Bencana Dan Perubahan Iklim Dalam Bingkai Kebijakan Publik

74 Tri Susantari

Demokrasi Indonesia yang Tak Pernah Berhasil Implementasi Kebijakan Pemerintah yang Bias Gender

75 Trisni Utami

Pembangunan Perkotaan Berwawasan Lingkungan Menuju Eco-Society

76 Triyono Lukmantoro

"Bully Politis", Dari Kerumunan Virtual Menuju Gerakan Sosial

77 Tutik Rachmawati; Resty Anggraeni

Partisipasi Politik Perempuan Di Kabupaten Toraja Utara

78 Wasisto Raharjo Jati

Kelas Menengah sebagai Basis Pembangunan Telaah Perspektif Webberian

870

79 Lampiran 1

Susunan Acara dan Agenda

80 Lampiran 2

Power Point Pembicara 
Susunan Panitia Seminar Nasional FISIP UNS

Dalam Rangka Dies Natalis Uns Ke 39

tema "Gender, Politik, dan Pembangunan di Indonesia: Perspektif Multidisiplin". Aula

FISIP UNS, Rabu, 22 April 2015

1. Penanggung Jawab : Prof. Drs. H. Pawito, Ph.D. (Dekan FISIP UNS).

2. Ketua Pengarah (Steering Committee): Prof. Dr. Ismi Dwi Astuti N., M.Si. Anggota:

1. Heni Prihutani, S.H.

2. Drs. Hamid Arifin, M.Si.

3. Dra. Hj. Suyatmi, M.S.

4. Drs. Is Hadri Utomo, M.Si.

5. Dra. Prahastiwi Utari, M.Si, Ph.D.

6. Dr. Drs. Bagus Haryono, M.Si.

7. Prof. Dr. Andrik Purwasito, D.E.A.

3. Ketua Pelaksana (Organizing Committee): Dr. Ahmad Zuber, S.Sos., D.E.A.

4. Sekretaris : Siti Zunariyah, S.Sos., M.Si.

Bendahara : Firdastin Ruthnia Yudiningrum, S.Sos, M.Si.

Seksi SPJ dan : Ir. Tardi, M.M.

Konsumsi

Seksi Persidangan : Sri Hastjarjo, S.Sos, Ph.D.

Seksi Akomodasi : Maryani, S.Sos.

(Booking Hotel)

Seksi Publikasi dan : Aris Surjanto, S.Sos.

Dokumentasi

(Pengumuman web Suhardi, A.Md.

site, Foto/ Video,

poster, Spanduk).

Seksi Perlengkapan,: Ir. Sri Lucyani, M.M.

Dekorasi, Sound

Daru Sasongko Kartika Aji, A.Md.

System, transportasi

Seksi Pengadaan : $\quad$ Sri Herwindya Baskara, S.Sos., M.Si.

Seminar Kit,

backdrop, sertifikat. 
- Seksi Daftar Peserta, : : Sugiyanto, S.Sos.

Daftar Hadir Maryani, S.Sos.

Pembicara, Penjaga

Daftar Hadir, SPPD.

Seksi MC : Monika Sri Yuliarti, S.Sos., M.Si.

口 Seksi Moderator Sesi : Drs. H. Supriyadi SN., S.U.

Pleno

口 Seksi Moderator Sesi : Sri Hastjarjo, S.Sos, Ph.D.

Paralel

Asal Wahyuni Erlin M., S.Sos., MPA.

Dr. Didik G. Suharto, S.Sos., M.Si.

Dr. Argyo Demartoto, M.Si.

Seksi Melibatkan : Dra. Hj. Suyatmi, M.S.

Mahasiswa

Pembicara Utama : $\quad$ 1. Prof. Dr. Ir. Keppi Sukesi, M.S.

(Universitas Brawijaya, Malang)

2. Drs. Fathan Subchi (Anggota DPR RI)

3. Prof. Drs. H. Pawito, Ph.D (Universitas Sebelas Maret, Surakarta)

4. Prof. Dr. Ismi Dwi Astuti N., M.Si.

(Universitas Sebelas Maret, Surakarta)

Moderator : Drs. H. Supriyadi Sn., S.U.

Seksi Proceeding 1. Dr. Ahmad Zuber, S.Sos., D.E.A.

2. Siti Zunariyah, S.Sos., M.Si. 


\title{
“BERPENAMPILAN MENARIK” \\ (Sketsa Budaya Konsumerisme dan Eksistensi Perempuan di Dunia Kerja)
}

\author{
Pangeran P.P.A. Nasution, S.Sos., M.A. \\ Program Studi Antropologi, FISIP, Universitas Malikussaleh \\ (pangeran9688@gmail.com)
}

\begin{abstract}
Abstrak
Sejak disematkan pertama sekali sebagai salah satu konsep utama bagi indikator pembangunan manusia oleh 'United Nations Development Program' pada Tahun 1995, kesetaraan gender hingga hari ini terus menjadi perhatian pemerintah dan masyarakat di seluruh dunia. Pemetaan terhadap berbagai area kritis dengan rangkaian catatan transformatif guna mewujudkan kesetaraan gender masih terus berlangsung. Kesetaraan gender mengajukan kehendak persamaan hak dan partisipasi dalam relasi gender, -suatu kehendak transformasi gender dengan langkah liberasi atas seluruh rupa penindasan, dominasi, dan diskriminasi (personal, kelas, hingga warna kulit yang berpotensi rasial): dalam spektrum ekonomi, sosial, kultural, maupun politik. Untuk itu, pada naskah gender ini, penulis akan mengajukan rangkaian telaah tentang semangat ekualitas gender, terutama relasi di antara kaum perempuan yang hingga hari ini diduga semakin mengarah kepada eksistensi berbasis pada sumberdaya (material) ekonomi. Gerak eksistensi perempuan semakin terkonsentrasi pada pertikaian dalam dunia kerja oleh agenda pembangunan para kapitalis. Di dunia kerja dan kisahnya, imajinasi eksistensi perempuan telah menyita perhatian kalangan pemilik modal (kaum kapitalis), dengan arena privatisasi yang tampil melalui ragam skenario pasar. Dalam satu telaah kritis, kehendak eksistensi perempuan kini tampaknya telah mengalami privatisasi akut, -berujung pada ilusi (romansa) atas ekualitas hak perempuan dalam akumulasi sumberdaya ekonomi, hingga penetrasi konsumerisme atas eksistensi daya-citra diri yang naif 'nan-diskriminatif'.

Kata kunci: eksistensi perempuan, dunia kerja, konsumerisme dan privatisasi.
\end{abstract}

\begin{abstract}
Since the first pinned once as one of the main concepts of human development indicators by United Nations Development Program (UNDP) in 1995, gender equality to this day continues to be a concern of government and society in the worldwide. Mapping of critical areas with a series of notes in order to realize the transformative gender equality is still ongoing. Gender equality and equal rights will apply for participation in gender relations, -the desire of gender transformation with liberalization measures over all such oppression, domination, and discrimination (personal, class, until the skin color that have the potential racial): the spectrum of economic, social, cultural, and politically. To that end, in this gender manuscript, the author will propose a series of study on gender equality spirit, especially the relations between women who up to this day leads to the existence of the alleged increasingly based on resources (material) economy. Motion existence of women increasingly concentrated in contention in the world of work by the capitalist development agenda. In the world of work and the story, imagination existence of women have seized the attention of the owners of capital (the capitalists), held by the privatization arena that appears through a variety of market scenarios. In a critical examination, the will of the women existence now seem to have suffered acute privatization, -ends at the illusion (romance) on equality rights of women in the accumulation of economic resources, to the penetration of consumerism on the existence of the self-image power that being naive and discriminatory.
\end{abstract}

Keywords: women's existence, the world of work, consumerism and privatization. 


\section{Pendahuluan}

Berbagai kajian yang menaruh perhatian terhadap isu gender oleh para akademisi, individu maupun lembaga yang bergeliat pada aras kesetaraan gender di Indonesia diperkirakan telah berlangsung sejak era pertengahan tahun 1980-an lalu. Kala itu merupakan fase baru bagi kehadiran dan berkembangnya kajian gender di ranah akademik. Gema kesetaraan gender senantiasa bersanding dengan terminologi ketimpangan gender yang memosisikan pengertian tentang kondisi perempuan dalam keterpurukan, tertinggal, tertindas, tersubordinasi, dan beragam kosmologi sejenis tentang marjinalisasi kaum perempuan dalam kehidupan sosial, ekonomi, kultural, dan politik lainnya (Fakih 1997; Irianto 2006; Megawangi 1999).

Larut dalam perkembangannya, kajian tentang gender pada dasarnya merupakan diskusi tentang perempuan dengan berbagai perbedaan yang ditampilkan dalam risalah kehidupan: kewarganegaraan, etnis, pendidikan, bahasa, keluarga, kelas, pekerjaan, dan ranah terkait lainnya. Bertendensi hirarki-androsentris dan menghadirkan ketidaksetaraan di antara kaum perempuan yang juga bersinggungan dengan ketidaksetaraan gender (Jackson dan Jones 2009). Terutama dalam dunia kerja, risalah gender seringkali mengungkapkan cara pandang terhadap kerja aktual perempuan yang berorientasi ke-ibuan (baca: pekerjaan rumah tangga) sehingga pekerjaan lain yang dilakukan mereka hanya sebagai suplementer atau sekunder. Bukan itu saja, rangkaian peristiwa ke-ibu-an mulai dari kehamilan, melahirkan, menyusui, hingga mengasuh anak dianggap sebagai kehendak 'alamiah' yang tidak berkualitas kerja (Mosse 1996).

Perempuan sebagai ibu rumah tangga sepertinya diperingati perayaannya ketika proses industrialisasi yang memungkinkan kaum lelaki dengan mobilitas tinggi meniru gaya hidup khalayak aristokrat, bersama seorang ibu rumah tangga dari anak-anaknya yang tidak perlu bekerja, namun dapat mewakili status dan kekayaan istrinya. Salah satu makna industrialisasi yang dikemukakan Moose (1996) selanjutnya, bahwa rumah tangga sebagai pusat produksi telah beranjak menjadi pusat konsumsi. Tanggung jawab rumah tangga sebagai pusat konsumsi yang terus berlangsung sampai hari ini mengakibatkan sebagian besar perempuan di berbagai negara, harus bekerja keras demi mendukung terhimpunnya sumberdaya ekonomi oleh kaum lelaki guna memenuhi kehendak konsumsi rumah tangga. Perempuan bekerja keras mengelola urusan rumah tangga sebagai representasi dikotomi feminin-maskulin, domestik-publik yang tidak dipandang aktif secara ekonomi.

Pengabadian dikotomi yang terus direproduksi itu diduga mengakar pada rentang dikotomi culture dan nature. Berangkat dari anggapan bahwa perubahan tatanan peradaban bergerak dari alam (perempuan) ke budaya (laki-laki), sehingga perempuan harus keluar dari arena domestik dan masuk ke arena publik untuk menjadi "manusia" yang berbudaya. Pengarusutamaan perempuan untuk terlibat aktif dalam arena publik melalui rentang nature dan culture, secara tidak langsung telah turut 'mengamini' bahwa untuk menjadi manusia dibutuhkan keabsahan atas proses konversi dari nature menuju culture. Menjadi manusia (bagi perempuan) dapat diartikan merubah perempuan 
"menjadi laki-laki", atau setidaknya menjadi sosok seperti yang diinginkan oleh laki-laki (Abdullah 2006a).

Eksistensi dikotomi dimaksud terus berlangsung dan berlanjut dalam sketsa kehidupan masyarakat yang menyamarkan sifat kenyataan diskriminatif dan bias gender dengan ideologi para kapitalis di balik tirai industri. Kehidupan masyarakat di wilayah perkotaan kini dipenuhi dengan kenyataan mistify yang mendisiplinkan kekaburan atas relung diskriminasi dan bias gender di dalam tatanan totalitarian atas kehendak punggawa kapitalisme (Mulyanto 2011). Seiring dengan proses industrialisasi dan penetrasi sistem kapitalisme ke dalam pasar tenaga kerja yang cenderung berkonsentrasi di kawasan perkotaan, status sosial ekonomi perempuan mengalami perubahan.

Teknologi yang diperkenalkan dan diterapkan dalam sistem kerja kota disesuaikan dengan kondisi laki-laki sehingga mendukung produktivitas laki-laki sebagai tenaga kerja industri di sektor publik. Begitu juga dengan rancangan sistem kerja kota, sama sekali tidak mendukung kegiatan ekonomi tradisional perempuan yang bisa dilakukan bersamaan dengan kegiatan sektor domestik. Akibatnya, perempuan (terdesak) mengupayakan penyesuaian masuk ke sektor publik dengan berpartisipasi sebagai tenaga kerja industri. Bukan sesuatu yang dikehendaki, dalam sektor (publik) ini mereka harus mengalami kondisi kerja yang buruk, dinilai memiliki produktivitas yang rendah, dan karenanya hanya memeroleh upah yang rendah (Esterik 1996; dalam Putranti 2004).

Representasi gender dalam kehidupan masyarakat perkotaan kini harus dipahami tidak hanya mencakup citra dan tekstualisasi dari pengalaman sosial modern, melainkan juga proses produksi, sirkulasi, dan konsumsi (Brooks 2011). Rangkaian perubahan status sosial ekonomi perempuan yang secara tegas berhubungan dengan proses industrialisasi yang berorientasi kepada eksistensi berbasis material, menjadi peristiwa yang menarik untuk ditelusuri selanjutnya di dalam tulisan ini.

\section{Menakar Eksistensi Perempuan dalam Ekspansi Pasar}

Secara umum tulisan ini berupaya mengungkap bagaimana bias gender yang tidak selalu antara laki-laki dan perempuan, namun juga memberi ekses bagi pertikaian (internal) di antara kaum perempuan guna meraih eksistensi dalam institusi industrial yang begitu maskulin. Selasar kota kini merupakan ruang yang diperebutkan dalam pertarungan gender (kaum perempuan) dengan batasan-batasan tradisi yang menjadi tidak stabil dan berubah-ubah, situs kontestasi eksistensi, hingga rima bandul konsumerisme yang berkehendak atas privatisasi gender.

Dalam upaya memahami realitas gender di dunia kerja, terutama di wilayah perkotaan, seruan praksis yang patut dicermati adalah dengan berefleksi pada catatan Abdullah (2006b), bahwa kehidupan masyarakat telah mengalami perubahan yang mendasar dalam berbagai aspek, sejak kultur agraris mulai dipertanyakan oleh kekuatan lain di luar dirinya. Pasar, dalam hal ini muncul sebagai kekuatan dalam membangun 'dunia' kehidupan sehari-hari, dengan memindah-mindahkan batas dan ikatan tradisional mengikuti logika berpikir pasar. Logika tatanan yang lebih didasari oleh daya beli penduduk, sehingga kekuatan ekonomi lebih menjadi alat atau faktor dalam identifikasi diri dan sosial. 
Selanjutnya, Abdullah (2006b) mengungkapkan bahwa globalisasi yang disokong oleh kalangan kapitalis mengakibatkan terintegrasinya ekonomi Indonesia pada pasar internasional, dan Indonesia adalah salah satu bagian dari pasar yang potensial untuk produk-produk global. Pembangunan dan perkembangan di bidang telekomunikasi dan transportasi menyebabkan keleluasaan bagi mengalirnya produk-produk global, sehingga di Indonesia barang-barang tersebut dapat dengan mudah diperoleh. Salah satu dampak dari kemudahan ini adalah terjadi perubahan pola "konsumsi" masyarakat. Globalisasi kemudian juga memengaruhi kehidupan sosial pada umumnya, yaitu terhadap faktorfaktor penting di dalam transfomasi masyarakat.

Dengan demikian, salah satu pengaruh besar dari globalisasi oleh para kapitalis adalah munculnya kebudayaan kota (urban culture) yang ditandai oleh hadirnya era ekonomi baru dan konsumerisme pada masyarakat di berbagai daerah di Indonesia. Suatu tatanan baru yang lahir tidak hanya merupakan suatu bentuk dan gaya baru yang dianut oleh masyarakat, tetapi juga suatu cara baru di dalam melihat diri sendiri dan orang lain di dalam konteks yang berbeda. Begitu juga dengan realitas gender yang kini terlibat dalam jaringan yang lebih kompleks yang melibatkan pasar.

Keberadaan pasar menjadi semakin tegas bagi eksistensi kaum perempuan dengan memperlihatkan posisi penting media yang mengkomunikasikan femininitas. Media dapat dilihat sebagai alat yang ampuh dalam menyebarkan bentukan dominan yang ada. Tentunya media beragam, sehingga media juga menentukan siapa pembacanya yang menerima bentukan yang ada. Dalam hal ini media yang menyebar umum menjadi sangat penting posisinya karena berbicara pada khalayak yang sangat beragam cirinya (Santoso 2006). Relasi antara market dan media kemudian dapat menjadi basis ideologi bagi praktik konstestasi hingga negosiasi dalam eksistensi perempuan di perkotaan (bandingkan dengan Abdullah 2006b).

Eksistensi kaum perempuan dalam hal kedudukan dan status sosial ekonomi sangat dipengaruhi oleh perputaran nilai kapital. Secara ekonomis, ketergantungan perempuan di pasar kerja dapat menguntungkan kelompok kapitalis karena biaya tenaga kerja yang ditawarkan seringkali benilai rendah (murah), dan kemudian keterlibatan perempuan dipandang sebagai suatu proses akumulasi kapital untuk mendapatkan keuntungan sebesar-besarnya. Perubahan status ekonomi juga berarti bagi perubahan pola konsumsi yang pada gilirannya turut menggerakkan sektor penyedia komoditi konsumsi, sebagai perangkat pendukung dalam pertarungan eksistensi perempuan (Haris 2006).

\section{“Berpenampilan Menarik": Dunia Kerja, Perempuan dan Tubuh yang Bergaya}

Eksistensi perempuan dalam skema industri para kapitalis, sepertinya merupakan representasi tentang perlawanan antar kelas (menengah) perempuan dalam partisipasi angkatan kerja sebagai tenaga kerja industri, dan juga partisipasi dalam konsumsi yang dimanfaatkan untuk memperkuat ketimpangan gender bagi keuntungan pasar dan kehendak para kapitalis. Di satu sisi, kaum perempuan didongengkan kisah takjub tentang ekualitas dalam kehidupan sosial-ekonomi melalui perayaan partisipasi perempuan di ruang publik. Namun di sisi yang lain, secara bersamaan, ternyata perempuan dihadapkan 
pada belenggu (eksploitasi) eksistensi melalui hasrat konsumerisme yang mendiskreditkan diri mereka antara satu dengan yang lainnya.

Dengan memadankan gaya refleksif dan dialog posfeminisme yang reseptif, selanjutnya dalam tulisan ini akan dikemukakan narasi gender tentang (eksistensi) perempuan dalam dunia kerja oleh kehendak kapitalis, melalui mekanisme pasar dan praktik konsumerisme yang akut.

\section{Narasi (Tubuh) Perempuan dalam Tradisi (Pekerja)}

Problematika dalam dunia kerja, termasuk keterasingan kerja merupakan salah satu topik diskusi dari studi perempuan yang berkaitan dengan isu politik, moralitas, hingga gaya hidup. Weeks (2011) menguraikan berbagai persoalan yang berkaitan dengan kerja, termasuk mengenai persoalan housework (kerja domestik), jam kerja, dan kaitannya dengan agenda perjuangan politik feminis. Weeks mengemukakan diskusi mengenai gagasan para Marxis otonom mengenai refusal of work (penolakan atas kerja) dan juga diskursus para feminis Marxis mengenai housework (kerja domestik). Weeks menyoroti permasalahan mekanisme privatisasi kerja yang hanya memaknai kerja sebagai cara untuk mempertahankan kehidupan, sekadar memeroleh penghasilan, dan bukan sebagai suatu konvensi sosial.

Mereka yang bekerja hanya fokus memberikan perhatiannya pada risalah yang berkaitan dengan kerja (secara individual). Lokus kerja masih diletakkan di arena privat, tidak dipandang sebagai suatu sistem atau tatanan hidup. Tempat kerja dipahami sebagai tempat yang privat, seperti "rumah tangga" ketimbang sebagai bagian dari struktur sosial. Selain itu, kerja juga masih dipahami sebagai pilihan individual, bukan sebagai suatu tatanan kekuatan politik. Weeks (2011) selanjutnya mengajukan gagasan Marx mengenai kerja, bahwa bukan hanya gagasan untuk membuat kerja menjadi publik tetapi juga untuk mempolitisasi kerja itu sendiri. Usaha untuk membuat kerja menjadi publik dan politis ini juga merupakan hal yang sangat penting karena bagaimanapun kerja bukanlah sekadar praktik pada aras ekonomi. Kerja merupakan aktivitas yang terintegrasi dalam ekonomi, sosial, politik, dan bahkan budaya.

Dalam budaya rumah tangga di Indonesia, misalkan, seorang suami adalah kepala keluarga dan istri adalah ibu rumah tangga, setidaknya begitu bunyi salah satu peraturan dalam Undang-undang Perkawinan: Pasal 31 (3). Selanjutnya, suami wajib melindungi isterinya dan memberikan segala sesuatu keperluan hidup berumah tangga sesuai dengan kemampuannya, dan pada pasal 34 (1): Isteri wajib mengatur urusan rumah tangga sebaik-baiknya. Kutipan-kutipan tadi mengungkapkan bahwa dalam hukum formal, struktur dalam rumah tangga bersifat asimetris, yaitu bapaklah yang menjadi pemimpin. Sang suami bergerak di luar rumah tangga untuk mencari nafkah sedangkan isteri adalah ibu rumah tangga yang tugasnya mengurus rumah tangga. Istri adalah orang yang tempatnya di rumah, tidak dimaksudkan bergerak di luar rumah. Pembagian kerja yang berdasarkan jenis kelamin ini merupakan gagasan budaya yang diabsahkan oleh hukum (Ihromi 1999).

Dalam kenyataannya, perempuan enggan untuk berada di dalam rumah saja. Tidak ubahnya seperti para lelaki, perempuan akan selalu menggali berbagai kesempatan 
dengan mendambakan tindakannya dapat menghasilkan sesuatu. Namun, seringkali pekerjaan-pekerjaan produktif dari wanita itu dianggap sebagai bagian dari pekerjaan rumah saja. Salah satu langkah populer yang dilakukan oleh perempuan di perkotaan adalah menjadi 'publik' dengan menyintas ke dunia kerja. Berpatisipasi dalam dunia kerja yang hingga hari ini tidak ubahnya 'pasar', dan merupakan institusi maskulin yang mereproduksi nilai seorang perempuan dengan sifat-sifat yang diturunkan dari ideologi patriarki (lihat Abdullah, 2006a).

Dalam iklan lowongan kerja, misalnya, tidak jarang ditemukan salah satu persyaratan bahwa pelamar kerja yang dapat mengajukan lamaran kerja adalah mereka yang memiliki 'penampilan menarik'. Syarat 'Berpenampilan menarik' itu turut menjadi syarat bagi menariknya ulasan di dalam tulisan ini. Betapa tidak, ketika para pelamar kerja mendapati syarat 'penampilan menarik' tersebut, sebagian dari mereka merasa terselamatkan karenanya sedangkan sebagian yang lain menjadi sedih dan murka. Mengapa demikian? Selanjutnya akan ditelusuri penjelasannya.

\section{Dunia Kerja dan Tubuh yang Bergaya: Antara Eksistensi dan Eksploitasi}

Pada bagian sebelumnya dikatakan bahwa menjadi 'publik' dengan berpartisipasi dalam pasar kerja merupakan salah satu langkah bagi eksistensi diri perempuan, salah satu upaya besar yang dilakukan untuk meyakinkan ke khalayak publik bahwa diri (pribadi) dalam keadaan terbaik. Ketika berupaya tampil di hadapan publik dan dengan penampilan yang terbaik, sadar atau tidak, kita sedang melibatkan tubuh dalam menampilkan diri kita di hadapan banyak orang. Tubuh yang sering dipandang sebagai fakta natural dan hanya berlangsung pada diri individu sebagai pemberian Tuhan, diterima begitu saja dan tidak diperdebatkan, ternyata telah memasuki ruang fakta sosial dimana ada berbagai kepentingan yang merasukinya. Kini makna tubuh kemudian didefinisikan; dikategorisasikan; dibedakan dan dikontrol oleh kehendak pasar.

Pemahaman ini juga dapat kita pahami dari narasi yang lain tentang fakta tubuh. Kita menyepakati bahwa menjadi gemuk adalah fakta natural pada tubuh, namun orang lain di sekitar kita ternyata juga mengajukan fakta sosial terhadap kegemukan pada tubuh kita. Dikatakan fakta sosial karena adanya wacana yang diajukan bahwa tubuh yang gemuk bukan sebagai tubuh ideal. Berbeda halnya pada dekade tahun 1960-an, ketika tubuh yang gemuk diidentikkan dengan kemakmuran, keidealan tubuh dan kesehatan. Transformasi "tubuh natural" ke "tubuh sosial" mengalami penjabaran serta definisi yang semakin kompleks. Tubuh individual yang pada awalnya diidentikkan dengan natural kemudian dimaknai secara utuh dan total, kini mengalami diferensiasi sesuai keinginan kekuatan sosial dan pasar.

Tubuh manusia menjadi ada karena diinterkorelasikan dengan tubuh manusia lainnya sehingga membentuk suatu pergulatan wacana. Dari setiap akselerasi gerakan tubuh, terjadi kesepakatan yang dihasilkan secara komunal. Keluarnya tubuh individu dari kesepakatan akan distigma sebagai pelanggaran yang menghendaki alienasi diri. Tubuh berbicara tentang respek terhadap situasi sekitarnya. Tubuh juga berhubungan dengan kesadaran tubuh dalam melakukan suatu respon disekitarnya. Tubuh cenderung mendiskursuskan komunikasi dalam bentuk non verbal seperti rasa cinta, benci, respek, 
takut hingga ketergantungan. Hal itu kemudian akan berdikotomi dengan lingkungan sekitarnya. Tubuh berkaitan dengan simbol sebagai suatu tanda yang disampaikan (revealed) sekaligus disembunyikan (concealed), simbol bagi segala sesuatu kejadian (Shilling 1993).

Tubuh juga merupakan kesatuan yang tidak terpisah dengan pikiran, menjalin suatu relasional dengan perasaan/emosi terhadap tubuh dirinya dan pemilik tubuh lainnya. Koneksitas antara mind dan body tergambar ketika manusia mengalami sakit maupun senang. Aktivitas body akan mengupayakan penyembuhan dengan berbagai perintah yang dilakukan oleh mind. Dua kecenderungan di atas menjelaskan bahwa mind cenderung mempunyai peran superior terhadap tubuh meskipun saling berkelindan. Secara simbolik tubuh merupakan suatu kumpulan/bercampurnya berbagai pemaknaan terhadap diri. Gesture yang ditampilkan oleh tubuh merupakan ekspresi yang memunculkan berbagai pengertian yang dapat terbaca oleh orang lain. Tubuh mempunyai keunikan tersendiri, meskipun tanpa mengeluarkan bunyi/kata-kata (chattered of words), tubuh mampu mengisyaratkan bahasa tersendiri yang nyaris sama, sehingga mampu dibaca dan dimengerti oleh orang lain (Synott 1993).

Dengan demikian, 'penampilan menarik' (khususnya dalam tulisan ini) sebagai salah satu syarat lamaran kerja telah menjadi 'fakta ketubuhan' yang bukan sekadar entitas natural, namun lebih sebagai entitas kultural dengan tendensi pertikaian gender di dalamnya. Berpenampilan menarik dalam ingatan sosial sebagian besar masyarakat dan bagi para pelamar kerja perempuan khususnya, merupakan tampilan tubuh yang langsing, postur tubuh yang tinggi, berwarna kulit terang (cerah), putih dan mulus. Fitur tubuh yang kencang dan segar dianggap paling ideal dan penuh kejayaan. Suatu ingatan gender yang jika ditelisik memiliki kesan kehendak maskulin sebagai acuan idealnya, dan mengonstruksi ekspektasi ketubuhan pada referensi syarat partisipasi dalam dunia kerja.

Tubuh kemudian diharapkan pada satu idealitas tertentu dalam dunia kerja untuk tidak mengalami pengenduran dan tidak terlihat kusam. Upaya pencapaian idealitas tubuh yang kencang, segar dan tidak terlihat kusam, dilakukan dengan kegiatan mengonsumsi berbagai produk kecantikan. Kekhawatiran terhadap tubuh yang tidak lagi terlihat cantik dan menarik, menyebabkan terbentuknya mitos akan kecantikan bagi kalangan perempuan. Mitos kecantikan memunculkan kehendak untuk membenci tubuh sendiri karena selalu merasa ada yang kurang. Pembayangan tentang tubuh yang ideal, seksi, serta berbagai perangkat material yang meyakinkan diri agar terlihat menarik, merupakan serangkaian hal ihwal dalam upaya mengenali tubuh yang sedang dipersiapkan untuk tampil di hadapan publik.

Tidak terbantahkan, berbagai kegiatan konsumsi terhadap tubuh kini merupakan keharusan. Kegiatan konsumsi tidak hanya meliputi konsumsi used-value dari suatu komoditi, tetapi juga meliputi konsumsi makna kebahagiaan, kenyamanan, kekayaan, kesuksesan, prestise, dan modernitas. Baudrillard mengklaim bahwa kegiatan konsumsi itu sejatinya merupakan konsumsi dari makna-makna tersebut. Dengan demikian, keterlibatan tubuh dalam kegiatan konsumsi kini mengalami perubahan disposisi tubuh ke arah disiplin terhadap kegiatan konsumsi dan mekanisme "pasar", Di titik inilah 
kemudian tubuh merayakan keberadaannya dalam gaya hidup dan dunia konsumtif. Keterlibatan tubuh terhadap gaya hidup maupun perilaku konsumerisme, dapat dikatakan sebagai resistensi tubuh pada segala sesuatu yang biologis (Chaney 2009; Lee 2006; Soedjatmiko 2008).

Penataan (tampilan) tubuh dalam dunia kerja yang dikontrol oleh mantra 'berpenampilan menarik' ditandai dengan mengawal keberadaan lemak pada tubuh perempuan. Mulai dari tubuh bagian atas, hingga bagian bawah (lower body). Penataan fitur tubuh ini dilakukan dengan menjaga pola makan, membeli berbagai perangkat untuk kepentingan berolahraga, hingga pemilihan makanan yang rendah lemak, tidak berminyak, dan juga menghindari rasa manis yang berlebihan. Menu makanan diseleksi secara ketat dan detil yang tidak jarang merujuk pada pencitraan oleh berbagai media (advertising).

Media massa turut berkontribusi terhadap ilusi dan mendistorsi tubuh untuk mengonsumsi suatu berita atau iklan (momentary alienated). Seperti ketika perempuan cantik harus sesuai iklan, berkulit putih, kurus, dan mulus. Realitas yang didengungkan media bahkan lebih sering intensitasnya dibanding realitas empiris yang terjadi, khususnya interaksi antara manusia. Beberapa implikasi dari intensitas hubungan dengan media adalah timbulnya kebencian terhadap tubuh sendiri diakibatkan terlampau sering melihat tubuh-tubuh ideal di dalam iklan. Jangankan berbicara tubuh ideal, makna tubuh yang normal kemudian juga berubah. Jika sebelumnya, tubuh gemuk, rambut kusam dan kulit gelap adalah bagian dari kenormalan, kini bergeser kepada sesuatu yang harus disingkirkan dan diperbaiki. Tubuh kemudian tersublimasi oleh wacana general yang digambarkan media dan diafirmasi oleh wacana kesepakatan umum masyarakat luas.

Dunia iklan yang menempatkan perempuan sebagai alat pembujuk sebuah produk menjadi basis kemerdekaan dan emansipasi perempuan dari ikatan domestik. Iklan secara jelas-jelas menempatkan perempuan pada posisi sebagai kelompok pengonsumsi terbesar produk-produk kapital. Tubuh individu mengalami ketidakpastian hasrat karena merasa tidak terpenuhinya keinginan dan pilihan akibat berlimpahnya iklan dalam media masa. Tubuh seperti mengalami kebingungan akibat melimpah ruahnya persediaan komoditi yang disajikan melalui media. Tubuh yang pada awalnya berada pada realitas empiris, menjadi kabur ketika masuk ke realitas media. Ia menjadi seolaholah nyata, dalam hal ini terdapat tarik-menarik tubuh antara realitas empiris dan realitas citra dengan media seakan direpresentasikan sebagai penengahnya.

Tubuh ideal sesuai afirmasi (pemihakan) sosial oleh penetrasi media telah membuat diri merasa lebih leluasa untuk mengenakan pakaian dengan mode apa saja, sehingga merasa lebih percaya diri untuk tampil di hadapan publik dengan meraih keberhasilan menjadi bagian dalam dunia kerja. Kreasi dalam berpakaian juga bagian penting dalam menampilkan tubuh terbaik di hadapan publik. Pakaian yang disesuaikan dengan konteks kerja dan merunut tren kekinian, modis, dan fashionable. Berbagai merk dan jenis pakaian dari rumah mode dunia serta perancang busana terkenal lainnya seperti Benetton, Chanel, Christian Dior, Levi's, Esprit, Hermes, Gucci, LV dan lain sebagainya tidak luput dari daftar afirmasi. 
Sebagaimana yang dikemukakan oleh Berger dan Luckman (1990), bahwa pakaian merupakan salah satu kebutuhan pokok yang tidak dapat dipisahkan dari manusia. Tanda atau sifat budaya yang terkandung dalam pakaian akan berubah dalam situasi atau kondisi yang berbeda-beda. Masyarakat tertentu telah mengatur sejenis pakaian tertentu yang layak untuk situasi tertentu pula. Pakaian merupakan salah satu benda budaya yang tidak bisa dipisahkan dari nilai-nilai yang ada pada suatu masyarakat. Ada hubungan dialektis antara individu dengan masyarakat karena nilai yang diberlakukan oleh suatu individu, sebenarnya merupakan hal-hal yang disahkan secara sosial oleh suatu masyarakat.

Pakaian merupakan salah satu cara dalam suatu interaksi antara satu individu dengan individu yang lain, sehingga pakaian merupakan produk material yang cenderung dimiliki oleh setiap orang. Pakaian ternyata mampu untuk menunjukkan keberadaan status seseorang. Pakaian merupakan suatu alat komunikasi yang dapat mengkomunikasikan siapa pemakainya. Dalam hal ini, pakaian menyuarakan keadaan maupun status individu dan kelompok, sehingga dapat dikatakan bahwa pakaian memiliki dimensi moral karena peranan dari pakaian sebagai penghubung keberadaan manusia sebagai mahluk individu dan mahluk sosial.

Sebagaimana pakaian perempuan dalam dunia kerja, seringkali tuntutan desainnya disesuaikan dengan bentuk alami tubuh sehingga memperlihatkan lekuk tubuh yang menghasilkan daya tarik erotik dengan sangkaan keindahan alami. Featherstone (1988) mengatakan bahwa peningkatan penampilan dengan pengenaan pakaian mode terakhir (kekinian), perawatan tubuh, dan juga wajah, akan menghasilkan citra diri yang bertambah atau menjadi lebih baik. Pakaian merupakan daya penarik seseorang yang membutuhkan perlindungan identitas, status, maupun kelas sosial.

Dengan begitu, penataan tubuh melalui pengguaan berbagai produk kosmetik telah dilakukan, pemilihan dan pengenaan perangkat (material) kecantikan terhadap tubuh, yaitu pakaian, juga telah dilaksanakan, maka, sepertinya tubuh tengah bersiap tampil di hadapan publik untuk 'berpenampilan menarik' yang dikehendaki dunia kerja. Ketika perempuan mengajukan diri di hadapan pasar kerja, disadari atau tidak, tubuh yang (berpenampilan menarik) terbaik hendak ditampilkan di antara tubuh-tubuh manusia lainnya dalam berbagai ruang publik, -di mana tubuh saling menilai, mengamati, dan mengawasi.

\section{Penutup: Kehendak Eksistensi yang Mendiskriminasi}

'Berpenampilan menarik' merupakan rekayasa kapitalis melalui mekanisme pasar terhadap dunia kerja, dan sebagai ruang publik dengan menurunkan intelektualitas yang semestinya berada di sana. Dunia kerja bagi perempuan merupakan ruang publik yang telah "dibajak secara khusus oleh kepentingan kelas tertentu", menyatir pernyataan Habermas (1989) dalam The Structural Transformation of the Public Sphere. Gerakan genial dan kesetaraan bagi ekspektasi perempuan dalam dunia kerja, hilang oleh wacana publik yang dibentuk oleh kapitalisme-pasar.

Kapitalisme 'pasar kerja' dengan imaji titik pandang maskulinitas seakan menghadirkan premis gender, bahwa ruang publik (dunia kerja) memang bukan untuk 
perempuan. Sebabnya, ketika perempuan masuk di dalam ruang publik, tanpa sadar akan terindoktrin dengan nilai 'patriarki' yang mengakibatkan mereka kembali terdampar dalam keadaan kesadaran palsu. Kembali lagi dalam masalah klasik feminisme dan perempuan, bahwa perempuan bukan kelas sosial sendiri, layaknya ruang publik yang menciptakan lagi ruang di dalamnya (khusus) bagi perempuan.

Begitu pula halnya yang terjadi pada tubuh perempuan dalam dunia kerja, 'berpenampilan menarik' seakan menjadi katu kunci bagi kehadiran perempuan dalam dunia (pasar) kerja. Tubuh perempuan seakan telah menjadi arena intervensi kekuatan dan pengujian kekuasaan di luar dirinya. Padahal, tubuh individu semestinya merupakan suatu hal yang otonom di mana setiap orang menjadi pengelola atas dirinya pribadi. Ketika tubuh sebagai entitas 'privat' mendapatkan arahan kontrol sosial, maka kebebasan guna mencapai hasrat eksistensi diri perempuan merupakan ilusi tanpa henti.

\section{Refleksi Kepatutan Tubuh (Berpenampilan Menarik) di Dunia Kerja}

Hasrat (desire) pada tubuh, menghadirkan perilaku dalam kegiatan konsumsi yang tidak terlepas dari hasrat untuk memproduksi identitas. Tubuh mempunyai kesadaran untuk memproduksi definisi-definisi diri. Hasrat juga dapat menghasilkan terjadinya ketergantungan melalui beragam replikasi dan simulasi gaya hidup. Posisi esensial ini sepertinya hendak menjelaskan bahwa hasrat eksistensi diri perempuan dalam dunia kerja, merupakan ilusi ekualitas gender sebagai fakta ketubuhan dengan jejaring ketidakpuasan yang tidak berujung, dan senang berulang. Kehendak ekualitas gender bagi perempuan seakan selalu bertentangan dengan kata "akhir", "penyelesaian" dan "berhenti".

Tatanan kapitalisme mengeksploitasi kehendak kebebasan perempuan. Kesempatan dalam dunia kerja ternyata tidak lebih dari masa-masa jahiliah bagi perempuan. Untuk itu, semestinya disepakati syarat 'intelektualitas' yang diutamakan dari 'berpenampilan menarik' bagi eksistensi perempuan di dalam dunia kerja. Jika tidak, bisa juga dengan tetap enggan, membiarkan mantra 'berpenampilan menarik' dalam dunia kerja mengakibatkan (tubuh) "perempuan menjadi serigala bagi perempuan lainnya".

\section{Daftar Pustaka}

Abdullah, Irwan. 2006a. "Dari Domestik ke Publik: Jalan Panjang Pencarian Identitas Perempuan”, dalam Abdullah, Irwan (ed). Sangkan Paran Gender. Yogyakarta: Pustaka Pelajar.

Abdullah Irwan. 2006b. "Dari Bounded System ke Borderless Society: Krisis Metode Antropologi dalam Memahami Masyarakat Masa Kini”. Jurnal Antropologi Indonesia 30(2):185-192.

Berger, Peter L. \& Luckman, T. 1990. Tafsir Sosial atas Kenyataan: Risalah tentang Sosiologi Pengetahuan. Jakarta: LP3ES.

Brooks, Ann. 2011. Posfeminisme \& Cultural Studies: Sebuah Pengantar Paling Komprehensif. Yogyakarta dan Bandung: Jalasutra.

Chaney, David. 2009. Lifestyle: Sebuah Pengantar Komprehensif. Yogyakarta dan Bandung: Jalasutra. 
Fakih, Mansour. 1997. Analisis Gender dan Transformasi Sosial. Yogyakarta: Pustaka Pelajar.

Featherstone, Mike. 1988. "Budaya Konsumen, Kekuatan Simbolis dan Universalitas", dalam Hans-Dieter Evers (ed). Teori Masyarakat: Proses Peradaban dalam Sistem Dunia Modern. Jakarta: Yayasan Obor Indonesia.

Habermas, Jurgen. 1989. The Structural Transformation of the Public Sphere. Massachusetts: MIT Press.

Haris, Abdul. 2006. "Mobilitas Angkatan Kerja Wanita Indonesia ke Luar Negeri", dalam Abdullah, Irwan (ed). Sangkan Paran Gender. Yogyakarta: Pustaka Pelajar.

Ihromi, T.O. 1999. "Paradigma Baru bagi Pengkajian Masalah Wanita dan Jender dalam Antropologi”. Jurnal Antropologi Indonesia 60:50-60.

Irianto, Sulistyowati. ed. 2006. Perempuan dan Hukum: Menuju Hukum yang Berperspektif Kesetaraan dan Keadilan. Jakarta: Yayasan Obor Indonesia.

Jackson, Stevie dan Jackie Jones, eds. 2009. Pengantar Teori-teori Feminis Kontemporer. Yogyakarta dan Bandung: Jalasutra.

Lee, Martyn J. 2006. Budaya Konsumen Terlahir Kembali: Arah Baru Modernitas dalam Kajian Model, Konsumsi, dan Kebudayaan. Yogyakarta: Kreasi Wacana.

Megawangi, Ratna. 1999. Membiarkan Berbeda?: Sudut Pandang Baru Tentang Relasi Gender. Bandung: Penerbit Mizan.

Moose, Julia C. 1996. Gender dan Pembangunan. Yogyakarta: Rifka Annisa Women's Crisis Centre dan Pustaka Pelajar.

Mulyanto, Dede. 2011. Antropologi Marx: Karl Marx Tentang Masyarakat dan Kebudayaan. Bandung: Ultimus.

Putranti, Basilica D. 2004. "Budaya, Negara, dan Status Sosial Ekonomi Perempuan: Sebuah Refleksi Konsep Ibu Rumah Tangga", dalam Faturochman, Bambang Wicaksono, Setiadi, dan Syahbudin Latief, eds. Dinamika Kependudukan dan Kebijakan. Yogyakarta: Pusat Studi Kependudukan dan Kebijakan, Universitas Gadjah Mada.

Santoso, Widjajanti M. 2006. "Menjadi Perempuan di dalam Sinetron: Kekinian Femininitas". Jurnal Antropologi Indonesia 30(1):36-48.

Shilling, Chris. 1993. "The Society Constructed Body", dalam Chris Shilling (ed). The Body and Social Theory. London: Sage Publications.

Soedjatmiko, Haryanto,. 2008. Saya Berbelanja, Maka Saya Ada: Ketika Konsumsi dan Desain Menjadi Gaya Hidup Konsumerisme. Yogyakarta dan Bandung: Jalasutra.

Synnott, Anthony 1993. The Body Social: Symbolism, Self, and Society. New York: Routledge.

Weeks, Kathi. 2011. The Problem with Work: Feminism, Marxism, Antiwork Politics, and Postwork Imaginaries. Durham, North Carolina: Duke University Press. 